\title{
赤血球の柤造と機能に関する研究
}

\section{I. 人及鷄の赤血球膜の構造について}

\author{
Studies on the Structure and Function of Red Blood Cells
}

\section{On the Structure of the Membrane of Human} and Chicken Red Blood Cells

\author{
益田栄* \\ Sakae MASUDA
}

\section{I. 緒言}

赤血球を溶血させた後に Ghost が残り，生 化学的には赤血球の表層に蔴糖分子以上の大き さの有機溶質を通過せしめない半透性を示す膜 のよ5なものを仮想し，それを赤血球の膜とい つていた。この膜についての生理学的研究は多 いが，形態学的な研究は案外少ない。然し袋状 のものがあることには一致している。電子顕微 鏡が用いられるようになつてから東，笹川，安 澄，丹野，大枝の諸氏によつて観察された。然 乙膜面の微細構造については処理する条件によ り変化するし，何れも普通乾燥法を用いている ので末だハッキリしない点がある。益田法によ る赤血球の研究汇於てもこの赤血球膜の性状が 重大な影響を及ぼすと考えられるので，特にこ の点も考光最も変化の少篎い方法を用い，尚鵎 の赤血球とも比較しつ〉観察した結果を報告す る。

\section{II. 材料と方法}

凝固を防ぐ意味で $4 \%$ チトラート液を加光人 及び鵎の血液を採取し，これに蒸溜水の中で滲 透圧的溶血を起させてから遠心分離してその膜 丈を集めこれを $1 \%$ オスミウム酸で固定する。 この膜浮遊液を霧滴にして凍結管の中を落下さ せ途中で霧滴の氷結したものをメッシュに捕集 乙真空中で乾燥させたものを電子顕微鏡で鏡検 した。立体的関係を明かにするためゲルマニウ

* 顺灭堂大学医学部触剖学教空 1957 年 9 月 20 日受付

\section{李嘉 章 * \\ Chia Chang LI}

ムで影をつけた。要するに赤血球の溶血した Ghost を凍結乾燥法を用い更にゲルマニウムで シャドウイングし電子顕微鏡で検した.

\section{III. 所見}

多数の赤血球を観察しその中で典型的なるの と思われる赤血球についての所見を述べる。

\section{1. 人の赤血球 (写真 1 参照)}

膜の一部が破けてその内容が流れ出し，その ためによく膜の内面までも観察出来た・この膜 の表面はつるつるしていて，内面には細かい孔 があり，ざらざらした膜である。即ちこの膜て は裏表があつてその表はつるつるし，裏はざら ざらしているらすい膜である。その破れたとこ らを見ても別段二層があるようには見られなか つた。これは丹野氏の 2 種の異なつた膠質層の はり合わさつた所見とも，大枝氏の網状をなす 膠質とそれを埋合せる膠質系のある所見ともち がつている。凍結乾燥法で処理したので変化の

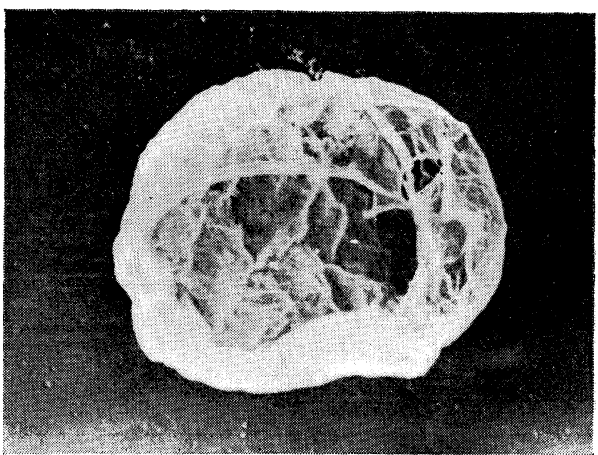

写真 1 人の赤血球 
少ないハツキリした像が得られたと思われる。

2. 鷄の赤血球

鶏の赤血球を溶血させ普通乾燥法 (写真 2), 凍結乾燥法 (写真 3) 飞影をつけたので比較する と，普通乾燥では一見センベイのように表層は 無情造で所々うすくなつたり，穴があつたりし て内部は網状か 線維状をなしているように見受 けられる。凍結乾燥では海綿様の球をなし，そ

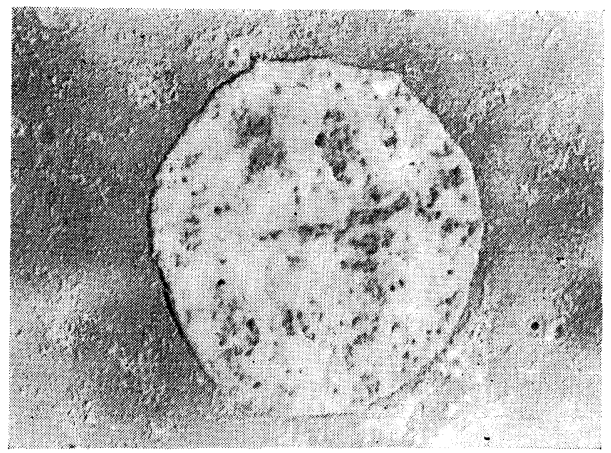

写真 2 鵎の赤血球（普通乾燥法）

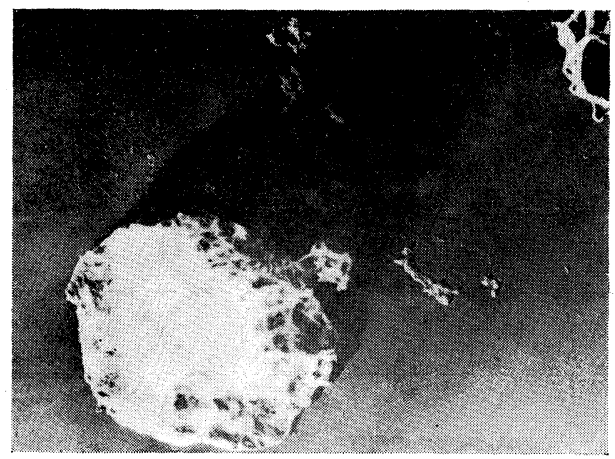

写真 3 鶏の赤血球

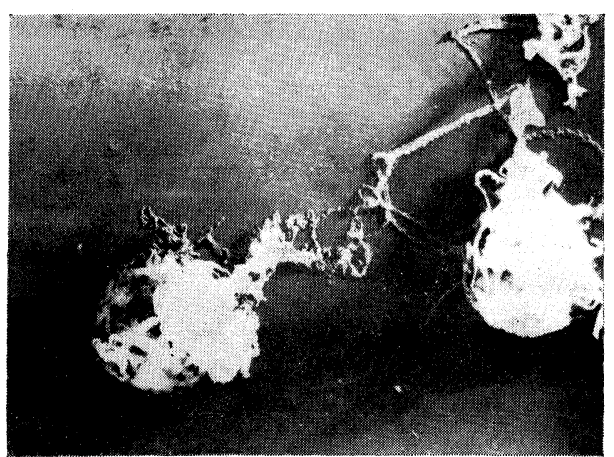

写真 4 鷄の赤血球（完全破壊）
の中に核が見られる。もつとひどく破壊されて 実質が外に流れ出したところ（写真4）ではヒモ 様のものが見られる。結局溶血の仕方も人のと はちがい，内容物は網状構造の基質の間にある もの丈が流れ出し，表面も大きな孔は出来ず小 さい孔が出来て流れ出す。七モ様物質で出来た 海綿体の中に核があり，形る球形をなしている ことは面白いことである。

\section{IV. 考察}

光学顕微鏡で溶血した赤血球の観察をして Lepeschinskaja (1925), Seifriz (1926), Bordersen (1927), Haden (1939) 等は袋状の膜が あることを主張した。電子顕微鏡で東，笹川， 安澄，丹野，大枝等もこの膜を確認している。 生化学的にも生理学的汇も大体膜の存在は確認 された，唯丹野氏はこの膜は二層あるといい，

Ponder は三層に分け外蛋白, 類脂質, 内蛋白 の層があるといつている，上述の所見でこの膜 は一枚の膜で裏表があつて表はつるつる裏はざ らざら告らすい膜であると思われる。Ponder の所見も Mudd 等によつて疑問視され，丹野 氏の二層もハッキリその切端が 確認されていな いので私達はむしろ一枚のうすい膜として考觉 れば，人の赤血球も鶏の赤血球も同じことがい えると思 5 。唯人の場合は内容が完全なゾルで 舀のはヒモ様構造を作る物質が含まれているの で, 両者の比較研究には充分これを考虑する必 要があり，溶血形式も異りいらいらな性質も変 つている. 従つて比較生理学, 生化学に於ては 充分人，鷂の赤血球を区别して研究する必要が あるよ5に思われる。

\section{V. 結 論}

人及び鵎の赤血球の血影を凍結乾燥法を用い シャドウイングして電子顕微鏡で観察した結果

1. 人及び鷄の赤血球に膜とも云うべきものを 確認した。

2.人の赤血球胑は裏表のあるら与い膜で表は つるつるし裏はざらざらしている。

3. 鶏の赤血球膜は5すく, 赤血球内部の七モ 
様基質の表面を被つている。

文献

4. 人及び鷄は赤血球の内部構造及び膜構造の 相異によつて溶血形式にも差異が認められるの

1) Lepeschinskaja, O.B.: Fol. haem. 31: 87, 1925.

で今後の研究にもこれを考慮する必要がある。

本研究に御援助下さつた日立中研の土倉氏に 感謝する。

2) Ponder, E.: Proc. roy, soc. London 97: 138, 1924.

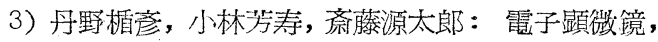
$1: 26,1950$.

4) 丹野楯㝘：電子蹎微鏡，2：47，1951.

5) 大枝：日新医学，39:170, 1951.

\section{Summary}

From the electron microscopic studies on the ghost of the red blood cell according to freezing-dry method, it is assumed that the red blood cell of human and chicken has the membrane. The membrane of the red blood cell of human is composed of one layer, its surface is smooth and its inner surface is rough. The membrane of the chicken red blood cell is thin and saround the fibrous stroma. The structure of the membrane of the red blood cell of human and chicken is different

Department of Anatony, Juntendo University, School of Medicine 